\title{
A EXPERIÊNCIA DA CARNE NA GENEALOGIA FOUCAULTIANA DA SUBJETIVIDADE
}

\author{
The experience of flesh in Foucault's genealogy of subjectivity \\ Malcom Guimarães Rodrigues *
}

Resumo: Nosso objetivo é interrogar em quais condições Foucault se depara com a noção de experiência da carne e defender a centralidade desta noção em sua genealogia da subjetividade. Pretendemos concluir que tal experiência, tal como o filósofo a compreende, pressupõe a análise de um conjunto de acontecimentos e de um conjunto de exercícios espirituais nos séculos II, III e IV.

Palavras-chave: Foucault. Subjetividade. Carne.

Abstract: This study aims to investigate the conditions that led Foucault to tackle the notion of the experience of the flesh and defend its centrality in the author's genealogy of subjectivity. Our conclusion intends to show that such an experience, as Foucault understood it, presupposes the analysis of a set of events and of spiritual exercises that took place in the second, third and fourth centuries.

Keywords: Foucault. Subjetivity. Flesh.

\footnotetext{
* Doutor em filosofia. Professor Titular do Departamento de Ciências Humanas e Filosofia da UEFS e Professor colaborador do Programa de Pós-graduação em Filosofia da UFBA. Apoio: CNPq. Artigo recebido em 31/07/2018 e aprovado para publicação em 10/03/2019.
} 

um modo de experiência, isso é, como um modo de conhecimento e de transformação de si por si, em função de uma certa relação entre anulação do mal e manifestação da verdade" ${ }^{\prime 1}$. O objetivo deste artigo é responder: como Foucault chega a esta formulação? Se a análise da noção de experiência da carne pressupõe o exame das razões pelas quais, para Foucault, a carne "deve ser compreendida como um modo de experiência...", antes desta análise urge investigar em quais condições o filósofo apresenta tal noção.

Por "condições" entenderemos dois conjuntos, característicos da emergência e do desenvolvimento da cultura de si cristã, analisados por Foucault entre 1980 e 1982. De um lado, até o século II, um conjunto de acontecimentos: a supervalorização do casamento, o declínio dos princípios de atividade e de isomorfismo, a conjugalização dos aphrodísia, a codificação das relações matrimoniais, a neutralização do prazer e, sobretudo, a "recentragem de todo o problema dos aphrodísia em torno do desejo" ${ }^{\prime 2}$. De outro, a partir do século II, um conjunto de exercícios: atividades que realizam o conhecimento e a transformação de si - tais como o ascetismo, a conversão e o exame de si - e o significado profundo de seus fins - a purificação, a salvação e a renúncia de si. Assim, o ascetismo mergulha o sujeito na verdade de si, a conversão faz deste mergulho um trabalho constante de vigilância, e o exame de si lhe impõe uma articulação entre manifestação da verdade e remissão das faltas.

De resto, será necessário ter em vista "o estabelecimento no cristianismo de dois novos elementos: a disciplina penitencial, a partir da segunda metade do segundo século, e a ascese monástica, a partir do fim do terceiro" $^{\prime 3}$. Dado que tais elementos são marcas da espiritualidade cristã, ao passo que, até o século II, temos eventos característicos da passagem entre paganismo e cristianismo, esta delicada passagem precisou ser analisada, na primeira seção deste artigo, assim como foi preciso apresentar aí um sucinto mapeamento do conceito de carne nas obras de Foucault. Em seguida, nos debruçamos sobre alguns aspectos situados ao redor do que o filósofo chama de supervalorização do casamento no Império romano do século II. Uma tensão entre o campo social e o sexual pode nos indicar a passagem do paganismo ao cristianismo ${ }^{4}$.

\footnotetext{
${ }^{1}$ FOUCAULT, M. Histoire de la sexualité 4. Les aveux de la chair. Paris: Gallimard, 2018a, p. 50-51.

${ }^{2}$ FOUCAULT, M. A hermenêutica do sujeito. Curso no Collège de France (1981-1982). Trad. Márcio A. da Fonseca e Salma T. Muchail. São Paulo: Martins Fontes, 2006a, p. 259.

${ }^{3}$ FOUCAULT, M. Histoire de la sexualité 4. Les aveux de la chair. Paris: Gallimard, 2018a, p. 50.

${ }^{4}$ FOUCAULT, M. Subjetividade e verdade. Curso no Collège de France (1980-1981). Trad. Rosemary C. Abílio. São Paulo: Martins Fontes, 2016, p. 64.
} 
Na segunda seção, as atenções se voltam para o desejo, pois "não estará mais em causa, na experiência cristã da carne, afirmar que o ato sexual, o desejo sexual, é incompatível com a verdade" ${ }^{\prime \prime}$. O desejo nos aparece como noção central na medida em que o cristianismo "mostrou a questão da verdade do desejo como aquela que o indivíduo precisava responder previamente para poder ter acesso, mais além de todo desejo sexual, à verdade mesma"6. Também, dado que "é o elemento necessário a ser controlado, a respeito do qual é preciso estabelecer pelo menos o princípio de uma relação de conhecimento, porque ele seria o ponto de partida da atividade sexual"7. Finalmente, porque "o desejo é o elemento fundamental e é nele (...) que é preciso concentrar todo o esforço. Daí a noção de concupiscência, que é o elemento básico, o alvo, o objeto real de toda a tecnologia cristã referente ao sexo" ${ }^{\prime \prime}$. Justificam-se, assim, como fios condutores de nossa terceira e última seção, de um lado, a cultura de si antiga - e, em particular, a assimilação cristã do modelo estoico de conhecimento de si - e, de outro, a passagem do desejo para a noção de concupiscência, na medida em que esta noção nos aparece como último passo em direção às condições nas quais Foucault se depara com a experiência da carne.

\section{A genealogia da subjetividade entre o paganismo e o cristianismo}

Pode ser dividida em três movimentos a primeira aparição do conceito de carne na obra de Foucault $t^{9} 1$ ) análise da penitência e da confissão dos pecados relacionais entre os séculos VII a XVI; 2) em seguida, a partir do Concílio de Trento, no século XVI, Foucault nos mostra como a atenção dos padres se volta para o corpo, não mais para a relação com o outro, mas à relação consigo - aqui entra em cena a "fisiologia moral da carne"; 3) doravante, o problema não está mais na superfície do corpo, mas na concupiscência, no desejo, na sexualidade. Por fim, reencontramos a pergunta levantada por Foucault no início de sua aula: "Como pôde acontecer que, bruscamente, no momento mesmo em que a anomalia se torna domínio de ingerência legítima da psiquiatria, a sexualidade passa a ser problema na psiquiatria?"10. Acontece que a correlação entre anomalia e sexualida-

\footnotetext{
${ }^{5}$ FOUCAULT, M. Subjetividade e verdade. Curso no Collège de France (1980-1981). Trad. Rosemary C. Abílio. São Paulo: Martins Fontes, 2016, p. 142.

${ }^{6}$ Ibid., p. 143.

${ }^{7}$ Ibid., p. 258.

${ }^{8}$ Ibid., p. 260.

9 FOUCAULT, M. "Aula de 19 de fevereiro de 1975". In: Os anormais. Curso no Collège de France (1974-1975). Trad. Eduardo Brandão. São Paulo: Martins Fontes, 2001.

${ }^{10}$ Ibid., p. 213.
} 
de, na psiquiatria, se tornou possível quando a medicina pedagógica da masturbação herdou ${ }^{11}$, naquilo que conhecemos como poder disciplinar, as técnicas pastorais de controle e docilização do corpo, patologizando-o, anormalizando-o, a partir de sua sexualidade. Assim, menos do que um declínio da cristianização, na vida moderna, assistimos a sua apropriação pelo Biopoder, que verteu os mecanismos cristãos de controle e verdade na forma jurídica e médica das instâncias modernas de gestão da vida ${ }^{12}$.

Em Os anormais, e também em $A$ vontade de saber, a distinção geral que interessa ao filósofo, em relação ao cristianismo, se dá entre a Idade Média e o início do período em que se consolidam os Estados modernos, a partir do século XVI, momento em que, por um lado, o padre acumula um sem-número de funções de gestão da vida privada, especialmente, com a complexificação das técnicas de penitência e confissão, e em que, por outro lado, o corpo do penitente será mais importante do que o aspecto relacional de sua vida social.

Comparativamente ao que vemos na década de 1980, há certo desinteresse nas aulas de Os anormais, em 1975, pelo cristianismo primitivo e pelos padres fundadores da igreja. Foucaul $\mathrm{t}^{13}$ começa a escrever sobre estes padres em agosto de 1977. Em janeiro de 1978, ele retoma o que mais tarde será uma parte de As confissões da carne - retomada que se faz notar nas aulas de 15 e 22 de fevereiro do curso Segurança, Território e População. Isso indica que, em 1975, o filósofo ainda não havia se detido sobre os textos cristãos da Antiguidade tardia - indicação confirmada por Senellart ${ }^{14}$ e detalhada por Gros $^{15}$. Mais interessado na segunda Idade Média, em particular, no período entre os séculos XII e XIII, e na passagem para o período subsequente, do Renascimento em diante, Foucault, em Os anormais, chega a mencionar o cristianismo primitivo, mas estende suas análises até a "penitência tarifada"16, no século VI - nada antes disso, como fará mais tarde.

O modo pelo qual compreende a noção de carne, em 1975, parece não destoar da perspectiva geral a partir da qual Foucault vai trabalhar esta noção daí em diante: a carne pode ser tomada em relação - seja de oposição, seja de aproximação - à sexualidade moderna. Não se trata de

\footnotetext{
${ }^{11}$ FOUCAULT, M. Dits et Écrits IV 1980-1988. Paris: Gallimard, 1994c, p. 295.

12 FOUCAULT, M. Malfazer, dizer verdadeiro. Função da confissão em juízo. Curso em Louvain, 1981. Trad. Ivone C. Benedetti. São Paulo: Martins Fontes, 2018b, p. 184. Ver também FOUCAULT, M. História da sexualidade 1. A vontade de saber. Trad. Maria T. C. Albuquerque. 13a ed. Rio de Janeiro: Graal, 1999, p. 22-29.

${ }^{13}$ FOUCAULT, M. Dits et Écrits I 1954-1969. Paris: Gallimard, 1994a, p. 51.

${ }^{14}$ FOUCAULT, M. Do governo dos vivos. Curso no Collège de France (1979-1980). Trad. Eduardo Brandão. Martins Fontes: São Paulo, 2014, p. 317.

${ }^{15}$ FOUCAULT, M. Histoire de la sexualité 4. Les aveux de la chair. Paris: Gallimard, 2018a, p. 8. ${ }^{16}$ FOUCAULT, M. Os anormais. Curso no Collège de France (1974-1975). Trad. Eduardo Brandão. São Paulo: Martins Fontes, 2001, p. 217.
} 
utilizar o termo "sexualidade moderna" para tratar da experiência cristã da carne, mas, com mais ou menos precisão, mesmo que a partir de interesses distintos, propor a compreensão da carne à luz da análise da experiência da sexualidade, "se entendemos por experiência a correlação, numa cultura, entre campos de saber, tipos de normatividade e formas de subjetividade"17. É assim que, depois da primeira aparição da noção de carne, em Os anormais, Foucault passará pelo tema diversas vezes: em 1976, em A vontade de saber; em 1977, na entrevista "O jogo de Michel Foucault", em que o filósofo lembra a centralidade de Tertuliano para suas análises. Depois, em 1978, no texto "Sexualidade e poder", no qual se lê: "A carne é a própria subjetividade do corpo, a carne cristã é a sexualidade presa no interior dessa subjetividade" ${ }^{18}$. Daí em diante, o conceito de carne aparecerá nos cursos Segurança, território e população, Subjetividade e Verdade e $A$ hermenêutica do sujeito. Além disso, em alguns escritos, como "O combate da castidade" (1982) e "Prefácio à História da sexualidade" (1984) e, evidentemente, nos livros que compõem A história da Sexualidade.

Apesar de todas estas referências, Foucault não publica um trabalho nem dedica um curso ou uma aula especificamente ao tema da carne. Mas, se a análise deste tema não figurou entre os objetivos principais do filósofo, não é porque a sexualidade se impôs como seu objeto principal.

Os anos de 1980 marcam uma mudança operada por Foucault sobre o tripé de sustentação de suas pesquisas genealógicas. Aos nossos interesses, digamos: do eixo poder-saber-sexualidade para o eixo governo-verdade-subjetividade. A noção de experiência da carne nos aparece como um dos efeitos desta mudança, uma ferramenta estratégica, entre outras, criada para situar e tratar de modo específico um conjunto de práticas, discursos, instituições e saberes característicos da espiritualidade cristã. Aos nossos propósitos, não convém atribuir a esta noção um lugar de destaque, em detrimento de outras, para além deste escopo estratégico que, diga-se, encontra ressonância nos cursos no Collège de France ${ }^{19}$.

Em Do governo dos vivos, embora não mencione a noção de experiência da carne, Foucault analisa o fio condutor que nos levará até ela: "esse regime

${ }^{17}$ FOUCAULT, M. História da sexualidade 2. O uso dos prazeres. Trad. Maria T. C. Albuquerque. $8^{\mathrm{a}}$ ed. Rio de Janeiro: Graal, 1998, p. 10.

${ }^{18}$ FOUCAULT, M. Dits et Écrits III 1976-1979. Paris: Gallimard, 1994b, p. 566.

${ }^{19}$ Para uma apresentação temático-cronológica dos três cursos entre 1980 e 1982, no Collège de France, ver os textos de "Situação do curso". Ver também, para o curso Do governo dos vivos, MANICKI, A. Técnicas de si e subjetivação no cristianismo primitivo. In: CANDIOTTO, C.; SOUZA, P. (Orgs.) Foucault e o cristianismo. Belo Horizonte: Autêntica, 2012, p. 57-74. Para Subjetividade e Verdade, ver CANDIOTTO, C. A emergência do homem de desejo. Sobre o curso Subjectivité et vérité, de Michel Foucault. In: Veritas. Porto Alegre, v. 60, n. 2, maio-ago. 2015, p. 344-365. Para A hermenêutica do sujeito, ver GROS, F. À propos de l'herméneutique du sujet. In: LE BLANC, G. \& TERREL, J. Foucault au Collège de France: un itinéraire. Bordeaux: Presses Universitaires de Bordeaux, 2003, p. 149-163. 
de verdade que a prática ritual da verbalização das faltas, inscrita no fundamento do sacramento de penitência, acabara ocultando. Dai a necessidade de remontar ao cristianismo primitivo" 20 . Algo parecido ocorre no segundo semestre de 1980, quando o filósofo vai aos EUA proferir três conferências ${ }^{21}$ nas quais discute as bases da referida noção, enquanto menciona muito de passagem a carne. Em 1981, surge a experiência da carne, mas a questão é outra em Subjetividade e Verdade: "como, às vésperas do cristianismo, as técnicas de vida, filosóficas e médicas, definiram e regularam a prática dos atos sexuais, a khrêsis aphrodísion?"22. Daí a importância da vida conjugal e das práticas matrimoniais, talvez, constituintes do ponto mais alto destas técnicas. No mesmo ano, Foucault ministra em Louvain o curso Malfazer, dizer verdadeiro. Mais uma vez, não há menção à experiência da carne. Em contrapartida, assiste-se a um aprofundamento das questões trabalhadas nas referências anteriores em diferentes direções - uma, em particular, que nos interessa de perto, porque retoma uma análise proposta e não absolutamente esgotada no curso de 1975: "mostrar como a verdicção do sujeito introduziu no direito penal, a partir do século XIX, uma crise da qual parece que ainda não saímos" ${ }^{23}$. A hermenêutica do sujeito é o curso em que os resultados das análises dos dois anos anteriores estão sendo apresentados já em direção a outra problematização, que encontra no cuidado de si sua expressão mais completa. Mas, quando ministra este curso, Foucault já cunhou a noção de experiência da carne que, nas aulas de 1982, sequer é mencionada pelo filósofo. Por fim, entre maio e junho deste ano, Foucault pronunciou um ciclo de seis conferências, sob o título Dire vrai sur soi-même, ao longo das quais pode-se notar que, se a carne é mencionada rapidamente, a análise do conhecimento de si em jogo na espiritualidade cristã, especialmente com Cassiano, é aprofundada significativamente ${ }^{24}$.

\footnotetext{
${ }^{20}$ SENELLART, M. Situação do curso. In: FOUCAULT, M. Do governo dos vivos. Curso no Collège de France (1979-1980). Trad. Eduardo Brandão. Martins Fontes: São Paulo, 2014, p. 303-304.

${ }^{21}$ Em outubro de 1980, Foucault vai a Berkeley, segundo Defert, "pronunciar duas conferências sobre "Truth and Subjectivity'" (FOUCAULT, M. Dits et Écrits I 1954-1969. Paris: Gallimard, 1994a, p. 58). Na nota de advertência do livro L'origine de l'herméneutique de soi, os editores chamam estas conferências de "Subjectivity and Truth". Seja como for, este é o primeiro de três trabalhos que Foucault apresentará nos EUA naquele ano. Em novembro, ele vai a Nova York e conduz um seminário que será parcialmente publicado em 1981, sob o título "Sexualité et solitude". Depois, Foucault vai a Dartmouth e pronuncia uma versão ligeiramente diferente das conferências realizadas em Berkeley, publicada no livro L'origine de l'herméneutique de soi.

${ }^{22}$ FOUCAULT, M. Resumo do curso. In: Subjetividade e verdade. Curso no Collège de France (1980-1981). Trad. Rosemary C. Abílio. São Paulo: Martins Fontes, 2016, p. 269. ${ }^{23}$ FOUCAULT, M. Malfazer, dizer verdadeiro. Função da confissão em juízo. Curso em Louvain, 1981. Trad. Ivone C. Benedetti. São Paulo: Martins Fontes, 2018b, p. 175.

${ }^{24}$ Sobre a carne, ver FOUCAULT, M. Dire vrai sur soi-même. Conférences prononcées à l'Université Victoria de Toronto, 1982. Édition, introduction et apparat critique par Henri-Paul Fruchaud et Daniele Lorenzini. Paris: Vrin, 2017, p. 121. Para a análise do conhecimento de si, ver, por exemplo, Ibid., p. 143.
} 
Como se vê, se as aulas de 1975 parecem dar o tom do modo pelo qual daí em diante a carne será tratada por Foucault - o tom da sexualidade, seja em oposição, seja em direção a ela - a partir de 1980, o cenário será outro. Em textos e aulas a partir deste período, vemos análises específicas e delimitadas que nunca deixam de destacar as continuidades e descontinuidades entre o paganismo, o cristianismo e a modernidade, ou, considerando o que nos interessa, entre as experiências dos aphrodísia, da carne e da sexualidade. Tal destaque, que pode encontrar sua expressão mais sintética na "5a Conferência" de Dire vrai sur soi-meme, de 1982, aparece de maneira esparsa em $O$ uso dos prazeres ${ }^{25}$ e em $O$ cuidado de $s^{26}$; e de modo mais sistemático nos cursos do Collège de France entre 1980 e 1982. Se a sexualidade, sem deixar de ocupar um lugar importante para Foucault, perde sua centralidade para a subjetividade, neste período, então, somente considerando a produção foucaultiana antes de 1980 é que ela pode figurar como fio condutor entre a genealogia da subjetividade e a experiência da carne. Afinal, "a carne não é absolutamente sinônimo de sexualidade" ${ }^{\prime 27}$. Não surpreende que o termo "sexualité" apareça apenas 2 vezes em todo o conteúdo de As confissões da carne: "mais do que me colocar no limiar de formação da experiência da sexualidade, tentei analisar a formação de certo modo de relação consigo, na experiência da carne" ${ }^{28}$. Isto nos é suficiente para, em primeiro lugar, justificar a importância de uma análise da carne sem reduzi-la a uma espécie de protosexualidade. Pode ser tentador realizar esta redução, sopesando os textos foucaultianos voltados ao eixo "poder-saber-sexualidade", mas não considerando os do eixo "governo-verdade-subjetividade", o qual deverá guiar nossa análise da experiência cristã ${ }^{29}$.

Em segundo lugar, se devemos nos ater ao que Foucault chama de carne, é imperioso destacá-la do cristianismo e do conflito de análises históricas ao seu redor. Com isso, nos comprometemos com o método foucaultiano: não a história em blocos, por meio das lentes de uma análise em termos de grandes códigos que determinam condutas, mas "qual experiência foi definida, proposta, prescrita para os sujeitos e levou-os a fazer determinada experiência de si mesmos a partir da qual precisamente a codificação de sua conduta, de seus atos, de seus pensamentos, se tornou possível"30.

\footnotetext{
${ }^{25}$ FOUCAULT, M. História da sexualidade 2. O uso dos prazeres. Trad. Maria T. C. Albuquerque. 8a ed. Rio de Janeiro: Graal, 1998, p. 30-31.

${ }^{26}$ FOUCAULT, M. História da sexualidade 3. O cuidado de si. Trad. Maria T. C. Albuquerque. $8^{a}$ ed. Rio de Janeiro: Graal, 2005, p. 41.

${ }^{27}$ FOUCAULT, M. Dits et Écrits IV 1980-1988. Paris: Gallimard, 1994c, p. 661.

${ }^{28}$ Ibid., p. 584.

${ }^{29}$ FOUCAULT, M. História da sexualidade 2. O uso dos prazeres. Trad. Maria T. C. Albuquerque. 8aㅡ. ed. Rio de Janeiro: Graal, 1998, p. 10-11.

${ }^{30}$ FOUCAULT, M. Subjetividade e verdade. Curso no Collège de France (1980-1981). Trad. Rosemary C. Abílio. São Paulo: Martins Fontes, 2016, p. 91.

${ }^{31}$ FOUCAULT, M. Dits et Écrits IV 1980-1988. Paris: Gallimard, 1994c, p. 583.
} 
Portanto, em terceiro lugar, a noção de experiência ${ }^{31}$. Em particular, a experiência da carne como uma lenta e constante mutação no modo pelo qual os sujeitos se relacionam consigo e com os outros, e não como um manto que vem de cima para definir e codificar sua subjetividade ${ }^{32}$.

Por fim, a delimitação temática da carne nos impõe uma indagação capital: para Foucault, o que caracteriza a oposição entre paganismo e cristianismo? Entre os comentadores, a referência mais conhecida para responder à pergunta ainda parece ser o livro de Chevallier, Michel Foucault et le christianisme. Organizada por Candiotto e Souza, temos a coletânea Foucault e o cristianismo, da qual merecem destaque algumas posições críticas à análise foucaultiana do cristianismo. Michel Senellart, por exemplo, nos mostra que esta análise "se caracteriza, na verdade, pela colocação à distância de três problemas maiores da historiografia do cristianismo: o da fundação, o da escatologia e a relação entre os poderes espiritual e temporal" ${ }^{\prime 3}$. Chevallier, por sua vez, é mais incisivo: "Foucault parece fazer do cristianismo um conceito unificado, dando-lhe uma definição relativamente estreita" ${ }^{34}$. Ambos concordam, em todo caso, que, na contramão de boa parte da analítica historiográfica cristã, Foucault não se detém sobre os modos de salvação a partir da perfeição e da fé, mas do reconhecimento das faltas e da confissão.

Passo arriscado seria deduzir daí que o filósofo se ocupa apenas da moral sexual, na oposição entre cristianismo e paganismo, até porque "não existe uma moral sexual do paganismo, assim como sem dúvida não existe uma moral sexual do cristianismo" ${ }^{35}$, diz-nos Foucault no curso em que são recorrentemente apontadas dificuldades que se instalam ao redor da referida oposição, a ponto de lermos que "seria imprudente falar do cristianismo como se $o$ cristianismo existisse" ${ }^{\prime 36}$. Para atravessar tais dificuldades sem muitos problemas, digamos que o cristianismo começa com o nascimento de Cristo e a espiritualidade cristã nos séculos IV e $V^{37}$. De modo que,

\footnotetext{
${ }^{32}$ De modo relativamente análogo à noção de experiência, Foucault (Subjetividade e verdade. Curso no Collège de France (1980-1981). Trad. Rosemary C. Abílio. São Paulo: Martins Fontes, 2016, p. 101) utiliza a noção de "percepção ética". Já a "substância ética" marca a distância destas noções (experiência, percepção e substância) com a de sujeito como essência: "para os gregos, a substância ética eram atos ligados em sua unidade ao prazer e ao desejo; eram o que eles chamavam os aphrodísia; os quais eram tão diferentes da 'carne' cristã quanto da sexualidade" (FOUCAULT, M. Dits et Ecrits IV 1980-1988. Paris: Gallimard, 1994c, p. 619).

${ }_{33}$ SENELLART, M. Verdade e subjetividade: uma outra história do cristianismo? In: CANDIOTTO, C.; SOUZA, P. (Orgs.) Foucault e o cristianismo. Belo Horizonte: Autêntica, 2012, p. 74. ${ }^{34}$ CHEVALLIER, P. O cristianismo como confissão em Michel Foucault. In: CANDIOTTO, C.; SOUZA, P. (Orgs.) Foucault e o cristianismo. Belo Horizonte: Autêntica, 2012, p. 47.

${ }_{35}$ FOUCAULT, M. Subjetividade e verdade. Curso no Collège de France (1980-1981). Trad. Rosemary C. Abílio. São Paulo: Martins Fontes, 2016, p. 158.

${ }^{36}$ Ibid., p. 18.

${ }^{37}$ FOUCAULT, M. L'origine de l'hermenéutique de soi. Conférences prononcées à Dartmouth College, 1980. Paris: Vrin, 2013, p. 126.
} 
se surge neste período, a experiência da carne pode se confundir com a espiritualidade cristã, mas não com o cristianismo ${ }^{38}$. Tampouco o termo espiritualidade cristã deve ser confundido com a espiritualidade "ocidental", mencionada, por exemplo, no fim da primeira hora da primeira aula de $A$ hermenêutica do sujeito.

Resultado: por um lado, temos quatro termos para distinguir quatro conjuntos de questões, quatro tipos distintos de experiências: até o século II depois de Cristo, o paganismo; a partir do nascimento de Cristo, o cristianismo; a partir dos séculos IV e V, a experiência cristã da carne; por fim, a espiritualidade ocidental, período que compreende todos os anteriores até os séculos XVI e XVII, quer dizer, até o que Foucault chama de "momento cartesiano"39. Por outro lado, se a compreensão da noção de experiência da carne, tal como proposta por Foucault, pressupõe a distinção de acontecimentos que marcam a passagem do paganismo para o cristianismo, podemos dividir tal passagem em quatro subconjuntos: A) do séc. IV ao século I a. C.; B) daí até o século II; C) do século II ao IV; D) dos séculos IV e $\mathrm{V}$ em diante.

Quatro observações sobre esta divisão. Trata-se de um esquema para facilitar nossa análise da história que interessa a Foucault. Se há uma inevitável generalidade em suas bordas (subconjuntos A e D), é porque estamos mais interessados no que se passa entre estes limites. Ademais, seria possível nomear os períodos de clássico, helenístico, cristão primitivo e experiência cristã da carne, mas queremos insistir no fato de que, apesar de serem distinguíveis entre si, tais subconjuntos formam dois conjuntos, $A B$ e $C D$, entre os quais podemos situar a passagem do paganismo ao cristianismo, no século II, embora isso não nos permita inferir uma separação entre mundos. Por fim: para analisar cada um dos conjuntos e, especialmente, suas diferenças, Foucault se utiliza de noções e referências da Antiguidade e do cristianismo, indicando suas (des)continuidades e contrastes. Se nos é impossível retratar a riqueza desta análise, um acontecimento poderá nos servir de fio condutor até a experiência da carne: a supervalorização do casamento.

${ }^{38}$ FOUCAULT, M. Subjetividade e verdade. Curso no Collège de France (1980-1981). Trad. Rosemary C. Abílio. São Paulo: Martins Fontes, 2016, p. 159.

${ }^{39}$ FOUCAULT, M. A hermenêutica do sujeito. Curso no Collège de France (1981-1982). Trad. Márcio A. da Fonseca e Salma T. Muchail. São Paulo: Martins Fontes, 2006a, p. 18. Em 1984, uma entrevista retoma a questão: antes de Descartes, a verdade tem um preço, a saber, o trabalho sobre si; depois dele, "a evidência substitui a ascese" (FOUCAULT, M. Dits et Écrits IV 1980-1988. Paris: Gallimard, 1994c, p. 630). E, citando estas palavras, Hadot dispara: "Não estou completamente seguro de que isso seja exato". E encerra: "para Descartes, também a evidência só pode ser percebida graças a um exercício espiritual" (HADOT, P. Exercícios espirituais e filosofia antiga. Trad. Flávio F. Loque e Loraine de F. Oliveira. São Paulo: É Realizações Editora, 2014, p. 280). Ora, em A hermenêutica do sujeito, Foucault (op. cit., p. 430) já ia nesta direção cobrada por Hadot. Ver também Ibid., p. 444 n. 5. 


\section{A supervalorização do casamento: da elisão do prazer às profundezas do desejo}

Situar o ponto de encontro e desencontro entre moral pagã e moral cristã na supervalorização do casamento, consolidada no século II, não quer dizer que o casamento não era valorizado, e tampouco que inexistia uma economia restritiva em relação ao prazer, no mundo pagão, até mesmo na Grécia arcaica ${ }^{40}$. Neste mundo, como mostram detalhadamente $O$ uso dos prazeres e $O$ cuidado de si, o casamento é valorizado, mas nunca a ponto de se tornar a condição exclusiva para pensar, julgar e praticar a relação sexual. Com a supervalorização do casamento, temos um irreversível processo de subordinação e, em seguida, de neutralização, do prazer, em face do jogo matrimonial. Ao mesmo tempo, vemos ficar mais complexa e rica, neste jogo, a relação entre o desejo, a verdade e o "si" interior - ponto primordial do cristianismo primitivo. Ao redor da valorização do casamento, diz-nos Foucault ${ }^{41}$, assistimos a uma conjugalização dos aphrodísia na qual, em seguida, o cristianismo encontra sua herança moral. Nesta conjugalização, vai se constituindo uma codificação da vida matrimonial, no seio da qual o desejo sexual surge como locus da verdade de si: o ato sexual será compatível com o exercício do pensamento filosófico e a carne cristã aparecerá como a espessura que vai abrigar esta verdade ${ }^{42}$.

A supervalorização do casamento não pode ser atribuída ao mundo cristão, ainda que se deva imputar à espiritualidade cristã do fim do século IV "reflexões e textos destinados a orientar os cristãos casados em sua vida matrimonial"43 absolutamente desconhecidos ao mundo pagão. Na passagem do período correspondente ao que nomeamos como subconjunto A para o período $\mathrm{B}$, encontramos elementos que denotam, de modo tão sutil quanto significativo, mudanças relativas ao papel do casamento nas artes de viver do mundo pagão. Assim, em A, "todos os fins do casamento são fins transitivos nos quais o próprio casal [não é] por si mesmo [seu] próprio fim. O casal só se justifica na medida em que está em causa outra coisa que não ele mesmo (a cidade, os filhos, os bens etc.)"; já no subconjunto $\mathrm{B}$, "o casal, ao contrário, tem uma natureza bem particular, absolutamente específica, irredutível a qualquer outra. O casamento, de certo modo, dá origem a um casal intransitivo que, pelo menos em parte, é finalizado por si mesmo" ${ }^{\prime 4}$.

\footnotetext{
${ }^{40}$ FOUCAULT, M. Subjetividade e verdade. Curso no Collège de France (1980-1981). Trad. Rosemary C. Abílio. São Paulo: Martins Fontes, 2016, p. 135.

${ }^{41}$ Ibid., p. 134.

${ }^{42}$ Ibid., p. 151.

${ }^{43}$ FOUCAULT, M. Histoire de la sexualité 4. Les aveux de la chair. Paris: Gallimard, 2018a, p. 250.

${ }^{44}$ FOUCAULT, M. Subjetividade e verdade. Curso no Collège de France (1980-1981). Trad. Rosemary C. Abílio. São Paulo: Martins Fontes, 2016, p. 114. Aqui Foucault segue de perto P. Veyne (La famille et l'amour sous le Haut-Empire romain. In: Annales. Economies, Sociétés, Civilisations. $33^{e}$ année, n. 1, 1978, p. 35-63).
} 
Foucault estabelece o ponto central da transição entre A e B na divergência entre o Econômico, de Xenofonte, e um compêndio de fragmentos dedicados à vida matrimonial, assinados por Musônio Rufo, concernentes à natureza do desejo sexual do casal. Se a finalidade do casamento é sua prosperidade, como quer Musônio, é natural que o desejo pelo cônjuge não seja (apenas) sexual, mas seja, acima de tudo, desejo da vida em comunidade. Em Xenofonte, não há esta ênfase no casamento como finalidade da vida do casal, logo, não há necessidade de tomar o desejo sexual como desejo exclusivo de uma comunidade de existência. Xenofonte tem em vista a finalidade política do casamento: um meio para se alcançar um fim além da relação dual entre homem e mulher. Este é o ponto: o próprio Aristóteles afirmou que o homem é mais inclinado a viver a dois do que no interior da polis, diz-nos Foucault ${ }^{45}$, mas nunca defendeu que a relação dual é necessariamente definida pela comunidade entre homem e mulher. Diferentemente do que se passa em Aristóteles e Xenofonte, em Musônio, o prazer é cooptado pelo casamento dos sexos opostos.

Foucault não situa especificamente no texto de Musônio a neutralização do prazer atribuída ao estoicismo tardio, mas mostra como o caminho para ela é sedimentado por este texto, segundo o qual "o ato sexual não deve ser indexado ao prazer. Nunca é para seu prazer que o indivíduo deve ter relações sexuais no interior do casamento" ${ }^{46}$. Algo parecido se dá em Sobre o amor, do século II, no qual Plutarco não elimina o prazer como fim da relação sexual com a esposa, embora nunca deixe de frisar sua finalidade exclusivamente matrimonial ${ }^{47}$. Se a única relação sexual legítima é a que se realiza dentro do casamento, não há mais espaço para o prazer, porque este não pode ser a finalidade das relações sexuais matrimoniais. Esta finalidade deve ser a prosperidade do casamento (a procriação, família, a mulher e os filhos). É o primeiro passo em direção a um regime conjugal de controle e elisão do prazer, o qual se desdobrará na conjugalização dos aphrodísia.

É claro que o prazer sexual e o casamento eram temas caros também para o pensamento grego. Foucault nos mostra que a questão sobre a finalidade do casamento - que comporta perguntas como: se e em que medida é necessário, útil e bom casar-se? - atravessa toda a Antiguidade ${ }^{48}$. A exclusão do prazer como fim último da atividade sexual no casamento está presente na ética dos aphrodísia. A procriação é a finalidade do casamento, para Platão e Aristóteles. Mas daí não se segue a condenação sumária do

\footnotetext{
${ }^{45}$ FOUCAULT, M. Subjetividade e verdade. Curso no Collège de France (1980-1981). Trad. Rosemary C. Abílio. São Paulo: Martins Fontes, 2016, p. 120.

${ }^{46}$ FOUCAULT, M. Subjetividade e verdade. Curso no Collège de France (1980-1981). Trad. Rosemary C. Abílio. São Paulo: Martins Fontes, 2016, p. 147.

${ }^{47}$ Ibid., p. 148-149.

${ }^{48}$ Ibid., p. 96.
} 
prazer, uma vez que era absolutamente aceitável ter prazer fora do casamento, desde que sob certas condições. Foucault trata destas condições durante duas aulas consecutivas do curso Subjetividade e Verdade (em 28 de janeiro e em 04 de fevereiro de 1981), tendo como referência a Onirocrítica de Artemidoro. E resume em dois os princípios que regem - não como códigos, em formas jurídicas, mas como percepções éticas, em formas de experiência - a atividade sexual até o século II. O princípio do isomorfismo sociosexual, de acordo com o qual o valor da relação sexual entre dois indivíduos varia conforme o tipo de relação social que eles mantêm; e o princípio clássico de atividade, segundo o qual o único prazer aceitável é o do homem ativo ${ }^{49}$. Conclusão: se é possível e imprescindível estabelecer uma distância entre A e B, por um lado, também é necessário, por outro, distinguir este conjunto $\mathrm{AB}$ do conjunto $\mathrm{CD}$.

Em AB, está em jogo “a percepção ética que caracteriza uma experiência bem especificamente grega, greco-romana, helenística e romana, para a qual os gregos tinham uma palavra precisa: aphrodísia" ${ }^{50}$. No século II, temos outro cenário. O princípio clássico de atividade foi perdendo sua importância, à medida que entregar-se a qualquer tipo de prazer passou a significar uma fraqueza, de modo que o indivíduo passivo seria, daí em diante, aquele que não consegue neutralizar seu prazer: "no século IV antes de Cristo, o ato sexual é uma atividade, enquanto, para os cristãos, é uma passividade" ${ }^{\prime 51}$. Por sua vez, o princípio do isomorfismo sociosexual foi progressivamente desarticulado, uma vez que o autodomínio pressupunha abrir mão de ter relações sexuais fora do casamento - e é nessa supervalorização do casamento que devemos ver a "elevação jurídica da mulher para o nível do homem, mas, inversamente, rebaixamento do prazer do homem para o nível do prazer da mulher"52. A supervalorização do casamento se opõe ao princípio do isomorfismo - porque eleva o estatuto moral da mulher e "rebaixa" o do homem - e tem como consequência a condenação da relação sexual fora do casamento. A valoração do ato sexual desvinculado do prazer cria um obstáculo intransponível ao princípio de atividade - porque tal ato passa a ser valorado em função do casamento e não mais da posição social do agente - e tem como consequência a desvalorização do prazer.

Compreende-se porque podemos tomar as implicações das mudanças no casamento como fio condutor da passagem do conjunto $\mathrm{AB}$ para o conjunto CD. O declínio dos princípios de isomorfismo e de atividade caracteriza o contexto de conjugalização dos aphrodísia. Mais do que isso: à medida

\footnotetext{
${ }^{49}$ Ibid., p. 94 e p. 147.

${ }^{50}$ Ibid., p. 69.

${ }^{51}$ FOUCAULT, M. Dits et Écrits IV 1980-1988. Paris: Gallimard, 1994c, p. 614.

${ }^{52}$ FOUCAULT, M. Subjetividade e verdade. Curso no Collège de France (1980-1981). Trad. Rosemary C. Abílio. São Paulo: Martins Fontes, 2016, p. 147.
} 
que o prazer é elidido, e que o casamento passa a ser um eixo ao redor do qual gravitam questões filosófico-morais, cresce a intensidade do isolamento e do trabalho sobre o desejo conjugal que, daí em diante, passa a se destacar de um todo do qual ele era inseparável.

Na percepção ética dos aphrodísia, o desejo sexual isolado não constitui em si um problema de acesso à verdade, tampouco um critério de regulação das relações sexuais. Isso porque, "em Platão e na filosofia grega a epithymía é uma instância geral de minha alma com relação à qual sou passivo", diz-nos Foucault53, e encerra: "A epithymía tornar-se a forma por excelência da manifestação em mim do próprio princípio de atividade sexual é algo novo e característico dessas tecnologias do si que se desenvolvem a partir dos séculos I e II". Muito mais importantes eram os princípios de isomorfismo e de atividade. A questão da verdade se colocava em função do conjunto desejo/ato/prazer. E o critério para julgá-lo provinha dos referidos princípios: o conjunto adveio de uma relação passiva ou ativa? De uma relação com um escravo ou com alguém socialmente superior? Assim, em AB, o critério para julgar o bom desejo/ato/prazer sexual não é o casamento em si, como sua finalidade única e exclusiva, e sim os princípios de isomorfismo e de atividade que regem as relações sócio-sexuais: se os aphrodísia representam e dão continuidade ao papel social do agente, e se este aparece como ativo em tais relações, estas são moralmente aceitáveis. A partir do século II, o critério da boa relação sexual é se ela é ou não realizada exclusivamente dentro do casamento, em seu benefício e em conformidade com os ritos que o regulam. Tornou-se cada vez mais importante um conjunto de regras a partir das quais este critério poderia surgir. Assim, por meio desta conjugalização dos aphrodísia, veremos surgir uma codificação, um conjunto de prescrições dirigidas às atividades sexuais matrimoniais e, em particular, ao desejo - e este é, sem dúvida, um divisor de águas.

Tanto para o pagão como para o cristão, a atividade sexual torna o indivíduo incapaz de ter acesso à verdade. Mas, para o primeiro, o sexo em si não é um problema, não levanta questões filosófico-morais. O problema é o apetite desenfreado, a cólera, enfim, os atos que denotam ausência de enkráteia em face de si e do outro. Por isso, os gregos não se cansaram de praticar, pensar e indagar um regime de autodomínio no qual eram relativamente indissociáveis a saúde do corpo e a excelência dos atos ${ }^{54}$. Neste regime, não há prioridade do desejo sobre o prazer ou vice-versa, ao contrário: "ato, desejo e prazer formam um conjunto cujos elementos, é verdade, podem ser distinguidos mas que são fortemente associados uns

${ }^{53}$ FOUCAULT, M. Subjetividade e verdade. Curso no Collège de France (1980-1981). Trad. Rosemary C. Abílio. São Paulo: Martins Fontes, 2016, p. 259.

${ }^{54}$ LEBRUN, G. A neutralização do prazer. In: MOURA, C. A. R et al. (Orgs.) A filosofia e a sua história. São Paulo: Cosac Naify, 2006. p. 476. 
aos outros" ${ }^{\prime 55}$. A partir do século II, este cenário muda. Não há dúvida de que o cristianismo primitivo se constitui, entre outras coisas, como uma espécie de assimilação singular das regulamentações estoicas relativas ao desejo e ao casamento. Além disso, pode-se dizer que houve uma forma de codificação da atividade sexual matrimonial já no estoicismo tardio, extremamente rudimentar se comparada ao que vemos no cristianismo, embora suficientemente eficaz no processo de neutralização do prazer $^{56}$. É verdade, enfim, que, desde Epicteto e Marco Aurélio, o autodomínio pressupõe não apenas um controle sobre o desejo, mas também a sua anulação $0^{57}$. Desse modo, a codificação do casamento e a anulação do desejo não estão presentes em $\mathrm{A}$, somente em $\mathrm{B}$ (ainda que, em $\mathrm{A}$, se trate de valorizar o casamento e resistir ao desejo). Não obstante, é preciso contextualizar as regulamentações estoicas matrimoniais no regime dos aphrodísia, à luz dos princípios de isomorfismo e de atividade, em $\mathrm{AB}$, e não na espiritualidade cristã, em $C D$, por uma razão muito simples: o paganismo não conheceu o desejo como o campo de atividade que, daí em diante, permitirá o acesso a isso que, na falta de termo melhor, chamaremos de abismo interior.

\section{Constituição e renúncia de si: do abismo interior à experiência da carne}

Em $\mathrm{AB}$, o trabalho sobre si pode se realizar como áskesis, os exercícios de si sobre si à luz da verdade, não nos termos de uma objetivação do sujeito, mas de uma constituição do sujeito como fim para si mesmo. Ocorre que, em CD, este fim será outro. Por isso, Foucault ${ }^{58}$ distingue três categorias de áskesis: a ascética, que visa à mudança do agente enquanto sujeito de ação e conhecimento verdadeiro; a ascese, que visa ao perdão, à salvação, à purificação ou a uma experiência espiritual qualquer; o ascetismo, que visa à renúncia ou à mortificação. Nestes termos, a ascese ou, especificamente, o ascetismo, podem ser o desdobramento da assimilação cristã das práticas ascéticas estoicas. Em tais práticas, certamente, há elementos de renúncia e austeridade, cujo objetivo é a constituição de uma relação plena e acabada de si para consigo. Acontece que, na ascese pagã, "a própria natureza dos meios, a tática, se quisermos, que é praticada para

\footnotetext{
${ }^{55}$ FOUCAULT, M. História da sexualidade 2. O uso dos prazeres. Trad. Maria T. C. Albuquerque. $8^{\text {a }}$ ed. Rio de Janeiro: Graal, 1998, p. 42.

${ }^{56}$ FOUCAULT, M. Subjetividade e verdade. Curso no Collège de France (1980-1981). Trad. Rosemary C. Abílio. São Paulo: Martins Fontes, 2016, p. 92.

${ }^{57}$ Ibid., p. 239 e p. 259.

${ }^{58}$ FOUCAULT, M. A hermenêutica do sujeito. Curso no Collège de France (1981-1982). Trad. Márcio A. da Fonseca e Salma T. Muchail. São Paulo: Martins Fontes, 2006a, p. 504.
} 
se chegar a este objetivo final não é primeira nem fundamentalmente uma renúncia" 59 , ao passo que, na ascese cristã, será um "sacrifício de partes sucessivas de si mesmo e renúncia final a si mesmo" ${ }^{\prime 60}$. Nesse ínterim, à medida que os exercícios de si sobre si pressupõem um movimento pelo qual o indivíduo se vira para o verdadeiro ao voltar-se para si mesmo, a áskesis vai na direção da metánoia.

A metánoia, como a áskesis, também deve ser compreendida em diferentes modalidades, ao menos três, tal como Foucault nos mostra na "Aula de 10 de fevereiro de 1982": em A, guiada pelo conhecimento de si platônico, trata-se de se desviar das aparências e descobrir em si as sementes da verdade; em B, guiada pelo cuidado de si estoico, trata-se de voltar os olhos para si no compasso em que se desvia o olhar do outro e das coisas do mundo; em $C$, guiada pela renúncia de si cristã, trata-se de um apelo a constituir-se como objeto de suspeita e vigilância. Importa notar que a conversão cristã, apesar de próxima da estoica, lhe introduz elementos desconhecidos, tais como a submissão, o arrependimento e a ruptura do eu. Epicteto e Marco Aurélio nunca aconselharam o arrepender-se, extraído do verbo metanoeîn, como forma de purificação nas práticas de $\mathrm{si}^{61}$. De modo semelhante, os aspectos da conversão proposta por Sêneca, que poderiam dar a impressão de ruptura e submissão do eu, indicam, na verdade, que esta ruptura "se dá em relação ao que cerca o eu. É em torno do eu, para que ele não seja mais escravo, dependente e cerceado, que se deve realizar esta ruptura" ${ }^{\prime 2}$.

Objetivo final e derradeiro da metánoia estoica, o eu, na conversão cristã, deve ser buscado a fim de se cindir. Mortificar-se para se salvar: é a regra do discípulo cristão, bem longe do estoico que escolhe livremente certas artes de viver para encontrar sua salvação na realização de uma forma de existência: "nesta salvação da filosofia helenística e romana, o eu é o agente, o objeto, o instrumento e a finalidade", já a salvação religiosa é "referida a um sistema binário, à dramaticidade de um acontecimento, a uma relação com o Outro e que, no cristianismo, implicará uma renúncia a si”63.

\footnotetext{
${ }^{59}$ Ibid., p. 386

${ }^{60}$ Ibid., p. 395.

${ }^{61}$ FOUCAULT, M. A hermenêutica do sujeito. Curso no Collège de France (1981-1982). Trad. Márcio A. da Fonseca e Salma T. Muchail. São Paulo: Martins Fontes, 2006a, p. 264.

${ }^{62}$ Ibid., p. 261.

${ }^{63}$ Ibid., p. 227. Mesmo tendo como objetivo a análise foucaultiana da metánoia, e não a vastíssima literatura de comentário a respeito, impossível ignorar a importância do livro de P. Hadot (Exercícios espirituais e filosofia antiga. Trad. Flávio F. Loque e Loraine de F. Oliveira. São Paulo: É Realizações Editora, 2014), e, sobretudo, de suas divergências com Foucault, para o qual o "eu" é a meta final da conversão estoica, ao passo que, para Hadot (ibid., p. 279): “Trata-se não da construção de um eu, como obra de arte, mas, ao contrário, de uma superação do eu". Assim, dirá Hadot (ibid., p. 298): “M. Foucault propõe uma cultura de si muito puramente estética, isto é, temo eu, uma nova forma de dandismo, versão final do século XX". Hadot pronuncia tais palavras em 1988, e é curioso ler o que, em 1982, já parecia
} 
O que são estas três condições da renúncia de si? Um sistema binário: a passagem da mortalidade à imortalidade, do reino do demônio ao reino de Deus, e assim por diante. A dramaticidade de um acontecimento: um evento súbito e transformador que abrirá caminho para o reconhecimento do pecado e da penitência - aqui poderíamos falar de exomologese. Por fim, a relação com o Outro: a submissão de si a um exame dirigido por seu mentor, obediência irrestrita ao diretor de consciência - aqui falaríamos da exagoreusis. Exomologese e exagoreusis nos remetem à penitência e à direção de consciência, que, ao lado do batismo, constituem "estas três formas de vinculação entre manifestação individual da verdade e remissão das faltas" ${ }^{64}$. Interessa-nos o modo como exomologese e exagoreusis aparecem como publicatio sui e como exame de si, respectivamente, em Tertuliano, no século III, e em Cassiano, no século IV.

Embora confundida com a confessio $0^{65}$, a publicação de si não é a confissão que veremos formulada e praticada a partir do século V. Tampouco é a "relação da subjetividade com a verdade, codificada em termos de direito, filtrada ao longo de uma prática discursiva" 66 , que vemos no século XII. A confissão pressupõe uma relação secreta, um âmbito de formulação verbal e uma função analítica e descritiva da falta, visando expor o pecado. Por sua vez, a publicação de si pressupõe um reconhecimento público, um âmbito performático e a função expressiva e teatral do faltante, visando expor o pecador. Sendo assim, a publicatio sui deverá ser praticada enquanto o pecador carregar consigo o pecado. Ora, isto é precisamente o que propõe Tertuliano, o "fundador" do pecado original ${ }^{67}$. E se carregamos desde sempre o pecado, uma disciplina penitencial deverá se difundir amplamente entre os cristãos, e a publicação de si se tornará imperativa à renúncia e à purificação de si.

\footnotetext{
uma resposta antecipada: "Como soam aos nossos ouvidos estas injunções a exaltar-se, a prestar culto a si mesmo, a voltar-se sobre si, a prestar serviço a si mesmo? Soam como uma espécie de desafio e de bravata, uma vontade de ruptura ética, uma espécie de dandismo moral" (FOUCAULT, M. A hermenêutica do sujeito. Curso no Collège de France (1981-1982). Trad. Márcio A. da Fonseca e Salma T. Muchail. São Paulo: Martins Fontes, 2006a, p. 16). ${ }^{64}$ FOUCAULT, M. Do governo dos vivos. Curso no Collège de France (1979-1980). Trad. Eduardo Brandão. Martins Fontes: São Paulo, 2014, p. 94-95.

${ }^{65}$ Sobre a etimologia e a importância da exomologese antes do século III, ver FOUCAULT, M. Do governo dos vivos. Curso no Collège de France (1979-1980). Trad. Eduardo Brandão. Martins Fontes: São Paulo, 2014, p. 185. Sobre as nuances que a distinguem de outras práticas cristãs, Ibid., p. 193. Sobre suas raízes não cristãs, Ibid., p. 207. Sobre sua distinção com a confessio, Ibid., p. 184. Ver também FOUCAULT, M. Histoire de la sexualité 4. Les aveux de la chair. Paris: Gallimard, 2018a, p. 89. Uma descrição detalhada da exagoreusis em FOUCAULT, M. Malfazer, dizer verdadeiro. Função da confissão em juízo. Curso em Louvain, 1981. Trad. Ivone C. Benedetti. São Paulo: Martins Fontes, 2018b, p. 142.

${ }^{66}$ FOUCAULT, M. Do governo dos vivos. Curso no Collège de France (1979-1980). Trad. Eduardo Brandão. Martins Fontes: São Paulo, 2014, p. 193.

${ }^{67}$ Ibid., p. 112.
} 
Assim, a despeito da controvérsia sobre o cristianismo se considerar ou não, até o século II, uma religião dos perfeitos, de pessoas incapazes de cair no pecado ${ }^{68}$, o fato é que, a partir do momento em que estamos manchados desde o princípio pelo mal, com a experiência do pecado original, "no interior da alma há um elemento que é o elemento do mal, há uma coisa que é um outro, e esse outro é o diabo"69. Se o mal habita e reina sobre a alma ${ }^{70}$, é muito menos no corpo do que no si-mesmo que devemos combatê-lo ${ }^{71}$. Rapidamente, justifica-se a penitência, a conversão, a mortificação espiritual - um trabalho sem fim sobre si: "o caminho rumo à verdade deve passar por essa expulsão do outro que está em nós, e deve passar por toda uma série de provas de verificação para saber se o outro continua lá" ${ }^{\prime 72}$. Eis que nos deparamos com uma matéria carnal pejada de seu próprio mal e que nos encaminha a um plano claramente distinto daquele enunciado pelo dualismo clássico "alma-perfeição x corpo-imperfeição". Para adentrar neste plano, podemos passar da metánoia à meléte.

Embora traduzida como "meditação", a meléte pagã não é um "jogo do sujeito com seu próprio pensamento, mas jogo efetuado pelo pensamento sobre o próprio sujeito"73. No mundo estoico, meléte é, de um lado, o exercício de apropriação de um pensamento, "de dele persuadir-se tão profundamente que, por um lado, acreditamos que ele seja verdadeiro e, por outro, podemos constantemente redizê-lo, redizê-lo tão logo a necessidade se imponha ou a ocasião se apresente"74. De outro, é o exercitar-se na coisa em que se pensa, tal como a meditação dos males futuros. Nestes termos, a meditação estoica guarda uma relação profunda com a escrita, a leitura e a escuta e, de modo geral, com o exame e a direção da consciência - noções que nos interessam porquanto nos situam na passagem à cultura de si no mundo cristão ${ }^{75}$. O que devemos analisar, nesta passagem, são mudanças no modo pelo qual o conhecimento de si aparece no exame e na direção de consciência. A esta análise, cabem duas observações preliminares, tendo em vista que a referida passagem

\footnotetext{
${ }^{68}$ Ibid., p. 158.

${ }^{69}$ Ibid., p. 115.

${ }^{70}$ FOUCAULT, M. Histoire de la sexualité 4. Les aveux de la chair. Paris: Gallimard, 2018a, p. 76.

${ }^{71}$ Palavras de Foucault (Malfazer, dizer verdadeiro. Função da confissão em juízo. Curso em Louvain, 1981. Trad. Ivone C. Benedetti. São Paulo: Martins Fontes, 2018b, p. 131), que, em seguida, completa: "O que o cristianismo inventou não é, absolutamente, o desprezo ao corpo [...], o que ele introduziu na cultura antiga creio ter sido o princípio de uma veridicção sobre si mesmo por meio de uma hermenêutica do pensamento".

${ }^{72}$ FOUCAULT, M. Do governo dos vivos. Curso no Collège de France (1979-1980). Trad. Eduardo Brandão. Martins Fontes: São Paulo, 2014, p. 145.

${ }^{73}$ FOUCAULT, M. A hermenêutica do sujeito. Curso no Collège de France (1981-1982). Trad. Márcio A. da Fonseca e Salma T. Muchail. São Paulo: Martins Fontes, 2006a, p. 430.

${ }^{74}$ Ibid., p. 429.

${ }^{75}$ Ibid., p. 585. Ver também FOUCAULT, M. Dire vrai sur soi-même. Conférences prononcées à l'Université Victoria de Toronto, 1982. Édition, introduction et apparat critique par Henri-Paul Fruchaud et Daniele Lorenzini. Paris: Vrin, 2017, p. 136.
} 
deve ser considerada à luz da "nebulosa de vocabulário e de expressões que transborda largamente o domínio circunscrito apenas pela atividade de conhecimento"76.

Em primeiro lugar, convém lembrar de que modo a cultura de si vai deixando de ter um papel meramente pedagógico, dirigida aos que querem governar, conforme o modelo platônico, e passa a se descentralizar, adquire um papel formador coextensivo à vida e acessível a todos, um parentesco mais claro com a medicina e um valor especial à velhice, conforme o modelo estoico. Neste modelo, o exame de si, herança do exame pitagórico, é realizado de modos distintos pela manhã e à noite, e consiste na "purificação da consciência por meio de um processo mnemônico"77. Trata-se de estabelecer um inventário sobre os pensamentos, um trabalho administrativo cuja finalidade é reativar regras de conduta, à título de correção técnica, não de punição ou censura. É preciso trazer à memória uma verdade esquecida, não no sentido platônico da reminiscência, mas para cotejar o que foi feito com o que deveria ter sido feito ${ }^{78}$. Este conhecimento de si implica um deslocamento por parte de quem o pratica, a valorização das coisas a partir de sua realidade no cosmos, a possibilidade para o indivíduo de ver a si mesmo e a transfiguração de seu modo de ser por efeito do saber ${ }^{79}$. Daí a importância da direção de consciência para o stultus, pessoa que negligencia a si e que não tem condições de sair de sua condição precisamente porque, nela, há uma desconexão entre sua vontade e seu eu. Uma vez que o stultus deve ser guiado, caberá a ele o silêncio e a escuta, e ao seu guia, a fala, ou seja, o dizer-verdadeiro, parrhesía. No estoicismo, "o peso essencial da verdade, a necessidade do dizer-verdadeiro, as regras às quais é preciso submeter-se ao dizer a verdade, para dizer a verdade e para que a verdade possa produzir seu efeito [...], tudo isso incide essencialmente sobre o lado do mestre" ${ }^{\prime \prime 0}$.

Em segundo lugar, se é este modelo estoico de conhecimento que o cristianismo herda, é preciso compreender esta herança à luz dos eventos que marcam a oposição entre cristianismo e gnose - por exemplo, da oposição de Tertuliano aos movimentos que rejeitavam o batismo ${ }^{81}$ - e o consequente esforço cristão para se desprender do modelo neoplatônico de conhecimento, característico da gnose. São estes eventos que teriam le-

\footnotetext{
${ }^{76}$ FOUCAULT, M. A hermenêutica do sujeito. Curso no Collège de France (1981-1982). Trad. Márcio A. da Fonseca e Salma T. Muchail. São Paulo: Martins Fontes, 2006a, p. 105

${ }_{77}$ FOUCAULT, M. Dits et Écrits IV 1980-1988. Paris: Gallimard, 1994c, p. 798.

${ }^{78}$ FOUCAULT, M. Do governo dos vivos. Curso no Collège de France (1979-1980). Trad. Eduardo Brandão. Martins Fontes: São Paulo, 2014, p. 216.

${ }^{79}$ Ibid., p. 223.

${ }^{80}$ FOUCAULT, M. A hermenêutica do sujeito. Curso no Collège de France (1981-1982). Trad. Márcio A. da Fonseca e Salma T. Muchail. São Paulo: Martins Fontes, 2006a, p. 493.

${ }^{81}$ FOUCAULT, M. Do governo dos vivos. Curso no Collège de France (1979-1980). Trad. Eduardo Brandão. Martins Fontes: São Paulo, 2014, p. 108.
} 
vado as instituições monásticas a recorrer à ascética estoica. Em todo caso, temos que esperar até o século IV para que tais instituições consolidem o cristianismo como a religião que oferecia a salvação na imperfeição, e o conhecimento de si como uma prática corrente e necessária a este fim, subordinada à direção (de consciência) sem a qual não há vida monástica ${ }^{82}$. Daí Foucault nos remeter à obra de João Cassiano - em vários momentos entre os anos de 1980 e 1982 e, é claro, na longa análise apresentada em As confissões da carne ${ }^{83}$ - e a contrapor ao estoicismo.

A partir do século IV, no mundo cristão, as artes de falar e escutar terão uma função bem diferente em relação àquela que exercem no estoicismo, para Foucault. A palavra, sempre à luz da Revelação e do Texto, dar-se-á como ensino, prescrição e direção, do ponto de vista do mestre, muito embora não caiba a este a erudição que cabia ao mestre antigo. E a escuta será, então, a escuta da verdade: verdade que não vem daquele que guia, e sim do que é guiado, do sujeito presente no discurso verdadeiro como objeto de seu próprio discurso e, doravante, obrigado "obedecer em tudo e não ocultar em nada" 84 . Nestas condições, o peso, a necessidade e as regras do discurso verdadeiro recaem sobre o discípulo, que deve estabelecer com seu mestre um vínculo permanente. Mais do que isso, recai sobre o discípulo cristão a obrigação de se submeter a uma regra de vida, rigorosamente controlada por si e dirigida pelo mestre.

Se o discípulo, na direção cristã, não estabelece com seu mestre um vínculo provisório e circunstancial, em direção à emancipação, como no estoicismo, mas um vínculo incondicional e permanente, em direção à obediência, é porque sempre haverá algo a dizer sobre si, algo que requer, assim, um abismo interior, nas profundezas do qual se esgueiram a verdade e o mal. "Abismo" porque "o cristão tem a verdade no fundo de si mesmo e é atrelado a esse segredo profundo", diz-nos Foucault ${ }^{85}$, e encerra: "ele está infindamente debruçado sobre si e infindamente obrigado a mostrar ao outro o tesouro que seu trabalho, seu pensamento, sua atenção, sua consciência, seu discurso, não param de extrair dele". Podemos falar de abismo interior, então, enquanto esta direção de consciência pressupõe infinitas camadas de interioridade para abrigar o que não está aí, à vista, porque se refugia em suas profundezas e pressupõe um trabalho sem fim de suspeita e exegese de si.

Quando este trabalho encontra um equilíbrio entre a ascese radical e o relaxamento, "nem no relaxamento nem no excesso de ascese, a isso Cassiano,

\footnotetext{
${ }^{82}$ Ibid., p. 235-238.

${ }^{83}$ FOUCAULT, M. Histoire de la sexualité 4. Les aveux de la chair. Paris: Gallimard, 2018a, p. 116-145.

${ }^{84}$ FOUCAULT, M. Do governo dos vivos. Curso no Collège de France (1979-1980). Trad. Eduardo Brandão. Martins Fontes: São Paulo, 2014, p. 241.

${ }^{85}$ Ibid., p. 283.
} 
como os outros autores cristãos, dá o nome de discretio" ${ }^{86}$. Necessária em função da natureza móvel do espírito humano, "que se mexe em todos os sentidos e em todas as direções e que é sacudido por toda uma multiplicidade de movimentos" ${ }^{\prime 87}$, a discretio é um trabalho de discriminação e análise, separação e julgamento. É um exame-reconhecimento das ilusões que se formam no interior da alma e do coração, exercício constante de decifração dos movimentos secretos do espírito. Ocorre que a discretio falta ao homem no compasso em que nele se faz presente o diabo, que assalta mesmo, e em especial, as almas mais puras. Logo, conhecer-se consiste em saber se a ideia está contaminada pelo mal, se veio (e/ou vai em direção) de Deus ou de Satã.

Por sua vez, o conhecimento de si estoico nunca pressupõe reconduzir os olhos da natureza para os mistérios malignos da consciência, das coisas exteriores para a secreta qualidade diabólica dos pensamentos. É verdade que não há exame de si sem "diálogo interior" 88 , para Sêneca, o qual não hesita em reconhecer a origem interior do mal" ${ }^{89}$, porém, "a ideia de que há um domínio de conhecimentos específicos a ser apreendido e elucidado - tamanho o poder de ilusão sobre nós mesmos, no interior de nós mesmos, e em razão da tentação - tudo isso é absolutamente estranho à análise de Sêneca" ${ }^{\prime 90}$. O que está em questão, para o estoico, é o conteúdo objetivo da representação, quer dizer, a natureza do objeto representado, e não do próprio pensamento. Trata-se de evocar princípios verdadeiros - não sobre a verdade de si, mas sobre a morte, a vida política e outros temas do cotidiano - e saber se e por qual razão fomos ou não tocados pela coisa representada: "é um saber sobre o mundo que é posto em prática em Marco Aurélio e nos estoicos. No caso de Cassiano e de outros será justamente uma decifração da interioridade, uma exegese do sujeito por ele mesmo" ${ }^{\prime \prime 1}$.

Para Cassiano, o perigo não está exatamente na agitação das paixões, mas dos pensamentos. $\mathrm{O}$ exame-reconhecimento proposto pelo monástico não deve mirar o objeto representado, seu conteúdo objetivo ou o mundo exte-

\footnotetext{
${ }^{86}$ Ibid., p. 263.

${ }^{87}$ FOUCAULT, M. Do governo dos vivos. Curso no Collège de France (1979-1980). Trad. Eduardo Brandão. Martins Fontes: São Paulo, 2014, p. 271.

${ }^{88}$ MOURA, A. R. Diálogo interior nas Cartas a Lucílio, de Sêneca. Ágora. Estudos clássicos em debate, no 17, 2015, p. 263-297. Lembremos que a questão da interioridade pode nos remeter muito além do mundo romano (HADOT, P. Exercícios espirituais antigos e "filosofia cristã". In: __ Exercícios espirituais e filosofia antiga. Trad. Flávio F. Loque e Loraine de F. Oliveira. São Paulo: É Realizações Editora, 2014, p. 67-68). Ver também Foucault, A hermenêutica do sujeito. Curso no Collège de France (1981-1982). Trad. Márcio A. da Fonseca e Salma T. Muchail. São Paulo: Martins Fontes, 2006a, p. 14.

${ }^{89}$ FOUCAULT, M. A hermenêutica do sujeito. Curso no Collège de France (1981-1982). Trad. Márcio A. da Fonseca e Salma T. Muchail. São Paulo: Martins Fontes, 2006a, p. 116.

${ }^{90}$ Ibid., p. 340.

${ }^{91}$ Ibid., p. 365.
} 
rior, e sim a própria representação, seu grau de pureza em sua "realidade psíquica" 92 , e assim, "esta é a primeira vez na história que os pensamentos são considerados como possíveis objetos de análise" ${ }^{\prime \prime 3}$. Os logismoi, tão caros à filosofia antiga, vão designar, nos textos de Cassiano, algo de duvidoso, suspeito, de um modo ou de outro, algo negativo ${ }^{94}$. Isso significa que "o espírito do mal e a alma são, ambos, da mesma natureza" ${ }^{\prime 5}$.

Testemunhamos, assim, a constituição de um campo de impressões que não encontra lugar na clássica separação corpo-alma ${ }^{96}$. É a concupiscência, a implicação entre o sujeito e seus pensamentos impuros. Afinal, o trabalho da discretio consiste, precisamente, em dissociar a vontade - mesmo a mais sutil e involuntária - do mal com o qual ela está implicada ${ }^{97}$. E toda vez que os pensamentos são reféns de um movimento provocador onírico, encontramos o que Cassiano chama de concupiscência ${ }^{98}$. No conhecimento de si da espiritualidade cristã, "o problema consiste essencialmente em saber se a ideia está ou não misturada com concupiscência" 99 . Esta se revela, destarte, como porta de acesso ao que chamamos de abismo interior, campo incomensurável a ser purificado em direção ao Divino. Não meramente lugar do erro e da ilusão, este campo é um processo que reúne, ao mesmo tempo, o mal e a única forma de combatê-lo, a única experiência através da qual a mortificação será possível - e este "através" deve ser lido em seu sentido mais literal. É assim que encontramos, a partir do século IV, este "modo de conhecimento e de transformação de si por si, em função de uma certa relação entre anulação do mal e manifestação da verdade", que Foucault chamará de experiência da carne.

\footnotetext{
${ }^{92}$ FOUCAULT, M. Do governo dos vivos. Curso no Collège de France (1979-1980). Trad. Eduardo Brandão. Martins Fontes: São Paulo, 2014, p. 274.

${ }^{93}$ FOUCAULT, M. L'origine de l'hermenéutique de soi. Conférences prononcées à Dartmouth College, 1980. Paris: Vrin, 2013, p. 83.

94 “O logismos grego era uma ação de pensamento, era um raciocínio: era uma noção neutra, ou até positiva. Ao contrário, nos textos da espiritualidade cristã, a palavra logismos e a palavra cogitatio, aliás usada principalmente no plural, são sempre termos pejorativos" (FOUCAULT, M. Malfazer, dizer verdadeiro. Função da confissão em juízo. Curso em Louvain, 1981. Trad. Ivone C. Benedetti. São Paulo: Martins Fontes, 2018b, p. 127). Ver também FOUCAULT, M. Do governo dos vivos. Curso no Collège de France (1979-1980). Trad. Eduardo Brandão. Martins Fontes: São Paulo, 2014, p. 271.

${ }^{95}$ FOUCAULT, M. Do governo dos vivos. Curso no Collège de France (1979-1980). Trad. Eduardo Brandão. Martins Fontes: São Paulo, 2014, p. 268.

${ }^{96}$ FOUCAULT, M. Dits et Écrits IV 1980-1988. Paris: Gallimard, 1994c, p. 303.

${ }^{97}$ FOUCAULT, M. Malfazer, dizer verdadeiro. Função da confissão em juízo. Curso em Louvain, 1981. Trad. Ivone C. Benedetti. São Paulo: Martins Fontes, 2018b, p. 129.

${ }^{98}$ FOUCAULT, M. Histoire de la sexualité 4. Les aveux de la chair. Paris: Gallimard, 2018a, p. 240.

${ }^{99}$ FOUCAULT, M. A hermenêutica do sujeito. Curso no Collège de France (1981-1982). Trad. Márcio A. da Fonseca e Salma T. Muchail. São Paulo: Martins Fontes, 2006a, p. 363.
} 


\section{Considerações finais}

Ao interrogar os termos - conhecimento e transformação de si, anulação do mal e manifestação da verdade - da "definição" foucaultiana de carne, fomos conduzidos às práticas cristãs de ascese, conversão e exame de si, de um lado, e para a purificação, a salvação e a renúncia de si, de outro. A compreensão destes termos pressupõe a análise de sua emergência na cultura de si do século II em diante. Esta análise, por sua vez, nos levou ao nosso ponto de partida: de um lado, a passagem do mundo grego para o mundo romano, do outro, da experiência greco-romana dos aphrodísia para a espiritualidade cristã. Nesta última, encontramos uma condição necessária da experiência da carne: a noção central de concupiscência. À margem da dualidade corpo-alma, esta noção inaugura um modo de relação a si que será objeto de um discurso que percorre, "sob a superfície dos pecados, a nervura ininterrupta da carne" ${ }^{\prime 100}$. Examinar, a partir do quarto volume de $A$ história da sexualidade, a relação profunda entre a concupiscência e outras noções (como a fornicação, a libido e a vontade) e práticas (como a virgindade) que passarão a orbitá-la de modo singular, certamente, é um passo importante em direção à compreensão da experiência da carne. Em nosso artigo, tentamos mostrar que há um passo prévio a esta compreensão, dado por Foucault, mormente, no início dos anos de 1980. Neste período, dois conjuntos se destacam entre as condições da formulação foucaultiana da noção de experiência da carne: um conjunto de acontecimentos (a supervalorização do casamento, a disciplina penitencial e o monaquismo) e um conjunto de atividades (o cuidado de si, a publicação de si e o exame de si). Some-se a estes dois, um terceiro: um conjunto de referências (os autores do estoicismo tardio, do cristianismo primitivo e da espiritualidade cristã). Vimos que, lendo textos estoicos e cristãos dedicados à cultura de si, Foucault se deparou com uma transformação no modo pelo qual o conhecimento abria caminho em direção ao extenso campo da concupiscência. Na falta de espaço para uma análise mais aprofundada sobre tal campo, adotamos a ideia de abismo interior. Falamos de uma interioridade - ao contrário daquela em questão no exame proposto pelo estoicismo tardio - cujo ser está sempre adiante de si mesmo, porquanto submerge a cada vez que dele nos aproximamos. E aqui vislumbramos o que nos parece a condição primeira para compreender a experiência da carne: a ideia de que o mal e a verdade, inseparáveis na espiritualidade cristã, estão sempre mais além, e por isso requerem uma imersão, uma queda, uma travessia sem fim que é este modo específico e contínuo da relação a si cristã. Condenado à pena perpétua da verdade, da decifração e da purificação de si, o cristão não terá outra escolha senão mergulhar

${ }^{100}$ FOUCAULT, M. História da sexualidade 1. A vontade de saber. Trad. Maria T. C. Albuquerque. 13 ${ }^{\underline{a}}$ ed. Rio de Janeiro: Graal, 1999, p. 22. 
neste abismo repleto de labirintos sombrios para deles extrair este si ao qual ele deve renunciar. Dizer que a carne deve ser compreendida como modo de experiência significa, portanto, que, por um lado, ela não pode ser pensada meramente como matéria sensível (tendões, músculos etc.), pois pressupõe o vasto e idiossincrático campo da concupiscência; nem, por outro, ser pensada metafisicamente, porque pressupõe uma série de práticas, instituições, discursos e saberes típicos do fim do século IV. Se, nestas condições, o abismo interior é a metáfora do que, bem mais tarde, vai abrigar o instinto e a anomalia, temas centrais para uma psiquiatria que é convocada a costurar a marca da sexualidade degenerada à tipificação criminal do século XIX, isto de modo algum implica uma continuidade entre a carne e a sexualidade, mas reforça a importância de repercorrer a história do pensamento ocidental "do ponto de vista dos efeitos que possam ter sido produzidos pelas formas bem específicas da espiritualidade que o cristianismo havia instaurado nos séculos IV-V de sua história"101.

\section{Referências}

CANDIOTTO, C.; SOUZA, P. (Orgs.) Foucault e o cristianismo. Belo Horizonte: Autêntica, 2012.

CANDIOTTO, C. A emergência do homem de desejo. Sobre o curso Subjectivité et vérité, de Michel Foucault. In: Veritas. Porto Alegre, v. 60, n. 2, maio-ago. 2015, p. 344-365.

CHEVALLIER, P. Michel Foucault et le christianisme. Paris: ENS Éditions, 2011 (coll. "La croisée des Chemins").

FOUCAULT, M. Dits et Écrits I 1954-1969. Paris: Gallimard, 1994a

FOUCAULT, M. Dits et Écrits III 1976-1979. Paris: Gallimard, 1994b.

FOUCAULT, M. Dits et Écrits IV 1980-1988. Paris: Gallimard, 1994c.

FOUCAULT, M. História da sexualidade 2. O uso dos prazeres. Trad. Maria T. C. Albuquerque. $8^{\mathrm{a}}$ ed. Rio de Janeiro: Graal, 1998.

FOUCAULT, M. História da sexualidade 1. A vontade de saber. Trad. Maria T. C. Albuquerque. 13 ed. Rio de Janeiro: Graal, 1999.

FOUCAULT, M. Os anormais. Curso no Collège de France (1974-1975). Trad. Eduardo Brandão. São Paulo: Martins Fontes, 2001.

FOUCAULT, M. História da sexualidade 3. O cuidado de si. Trad. Maria T. C. Albuquerque. $8^{\mathrm{a}}$ ed. Rio de Janeiro: Graal, 2005.

${ }^{101}$ FOUCAULT, M. Malfazer, dizer verdadeiro. Função da confissão em juízo. Curso em Louvain, 1981. Trad. Ivone C. Benedetti. São Paulo: Martins Fontes, 2018b, p. 148. Sobre a descontinuidade, ver FOUCAULT, M. Dits et Écrits IV 1980-1988. Paris: Gallimard, 1994c, p. 813. 
FOUCAULT, M. A hermenêutica do sujeito. Curso no Collège de France (1981-1982). Trad. Márcio A. da Fonseca e Salma T. Muchail. São Paulo: Martins Fontes, 2006.

FOUCAULT, M. L'origine de l'herméneutique de soi. Conférences prononcées à Dartmouth College, 1980. Paris: Vrin, 2013.

FOUCAULT, M. Do governo dos vivos. Curso no Collège de France (1979-1980). Trad. Eduardo Brandão. Martins Fontes: São Paulo, 2014.

FOUCAULT, M. Subjetividade e verdade. Curso no Collège de France (1980-1981). Trad. Rosemary C. Abílio. São Paulo: Martins Fontes, 2016.

FOUCAULT, M. Dire vrai sur soi-même. Conférences prononcées à l'Université Victoria de Toronto, 1982. Édition, introduction et apparat critique par Henri-Paul Fruchaud et Daniele Lorenzini. Paris: Vrin, 2017.

FOUCAULT, M. Histoire de la sexualité 4. Les aveux de la chair. Paris: Gallimard, 2018a.

FOUCAULT, M. Malfazer, dizer verdadeiro. Função da confissão em juízo. Curso em Louvain, 1981. Trad. Ivone C. Benedetti. São Paulo: Martins Fontes, 2018b.

GROS, F. À propos de l'herméneutique du sujet. In: LE BLANC, G. \& TERREL, J. Foucault au Collège de France: un itinéraire. Bordeaux: Presses Universitaires de Bordeaux, 2003, p. 149-163.

HADOT, P. Exercícios espirituais e filosofia antiga. Trad. Flávio F. Loque e Loraine de F. Oliveira. São Paulo: É Realizações Editora, 2014.

LEBRUN, G. A neutralização do prazer. In: MOURA, C. A. R et al. (Orgs.) A filosofia e a sua história. São Paulo: Cosac Naify, 2006. p. 451-80.

MOURA, A. R. Diálogo interior nas Cartas a Lucílio, de Sêneca. Ágora. Estudos clássicos em debate, $\mathrm{n}^{\mathrm{o}}$ 17, 2015, p. 263-297.

VEYNE, P. La famille et l'amour sous le Haut-Empire romain. In: Annales. Economies, sociétés, civilisations. $33^{\mathrm{e}}$ année, n. 1, 1978, p. 35-63.

Endereço do Autor:

Travessa dos Agrônomos, n. 72 - Condomínio Ametista, casa 55

Bairro: Jomafa

44090-112 Feira de Santana - BA

malcomgr@gmail.com. 